\title{
Jonson's Stage: Properties for Drinking and Eating in The Children of the Revels' Plays
}

Joanne Vine

\section{(2) OpenEdition}

\section{Journals}

\section{Electronic version}

URL: http://journals.openedition.org/shakespeare/1716

DOI: 10.4000/shakespeare.1716

ISSN: 2271-6424

\section{Publisher}

Société Française Shakespeare

\section{Printed version}

Date of publication: 3 March 2012

Number of pages: 105-116

ISBN: 2-9521475-8-2

\section{Electronic reference}

Joanne Vine, "Jonson's Stage: Properties for Drinking and Eating in The Children of the Revels' Plays

", Actes des congrès de la Société française Shakespeare [Online], 29 | 2012, Online since 03 March

2012, connection on 20 April 2019. URL : http://journals.openedition.org/shakespeare/1716 ; DOI :

10.4000/shakespeare.1716 


\section{Shakespeare et les arts de la table}

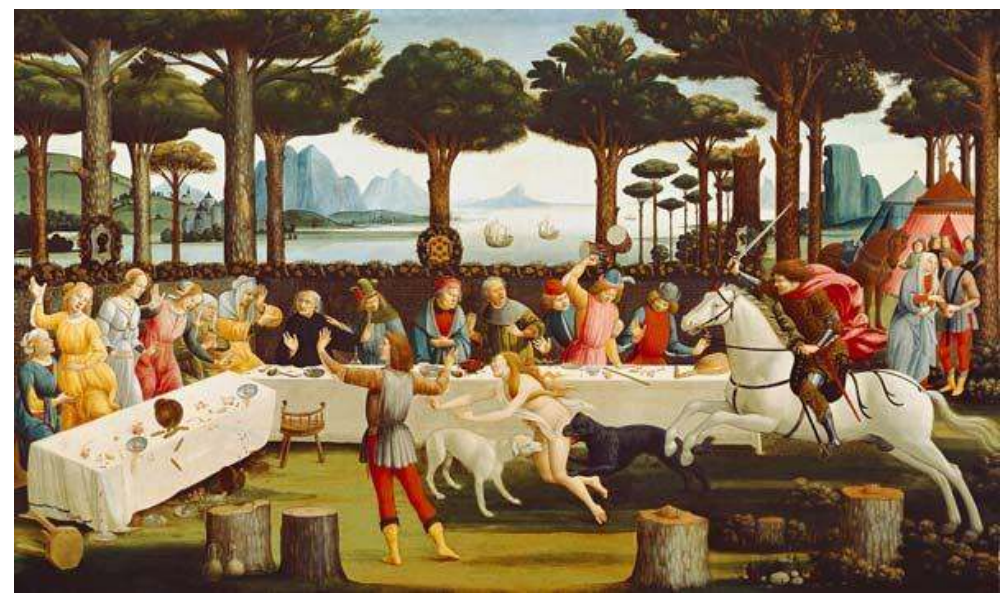

actes du Congrès

organisé par la

SOCIÉTÉ FRANÇAISE SHAKESPEARE

les 17, 18 et 19 mars 2011

textes réunis par

Christophe HAUSERMANN

et

Pierre KAPITANIAK

sous la direction de

Dominique GoY-BLANQUET 
COUVERTURE :

Botticelli, Banquet dans la forêt de pins,

Troisième tableau de la série

"L'histoire de Nastagio degli Onesti » inspiré d'une nouvelle du Décaméron de Boccace Musée du Prado, Madrid

conception graphique et logo

Pierre Kapitaniak

mise en page et corrections

Christophe Hausermann

Pierre Kapitaniak

(C) 2011 Société Française Shakespeare Institut du Monde Anglophone Université de Paris III - Sorbonne Nouvelle 5 rue de l'École de Médecine 75006 Paris

www.societefrancaiseshakespeare.org

Tous droits de traduction, de reproduction et d'adaptation réservés pour tous les pays 


\title{
Jonson's Stage: Properties for Drinking AND Eating in The Children Of The Revels' Plays
}

\author{
Joanne VINE
}

\begin{abstract}
Jonson was infamously a bon vivant. He grew to 20 stone and was known to be a heavy drinker. Jonson's poetry mirrors his biography: in "Leges Conviviales", Jonson describes the taverns with which he was so familiar, as well as the properties they should contain; he foregrounds the importance of "delight[ing] in excess" that characterised his personal life; and argues that "good wine" is essential. Paradoxically, as this paper will show, Jonson's plays for The Children of the Revels demand few scenes of eating and drinking, which contrasts strongly with plays by his contemporaries writing for the same company. This paper will interrogate the lack of drinking and eating vessels in The Case is Altered, Cynthia's Revels, Epicœne and Poetaster. I will build upon recent interest in the materiality of the stage from critics such as Natasha Korda, Andrew Gurr and Andrew Sofer, as well as those who examine the work of individual theatrical companies - like Lucy Munro, Scott McMillin and Sally-Beth MacLean - to offer a new view of Jonson's attitude towards on-stage consumption.
\end{abstract}

Jonson était réputé pour être un bon vivant. II pesa jusqu'à cent trente kilos et il était connu pour être un grand buveur. Sa poésie nous offre quelques éléments biographiques : dans "Leges Conviviales », Jonson décrit les tavernes qu'il fréquentait ainsi que les accessoires qui devaient s'y trouver. II prône la nécessité de "se complaire dans les excès », règle qu'il adopta dans sa vie personnelle, et il prétend que le "bon vin » est essentiel. Cette étude vise à montrer le paradoxe existant entre la vie de Jonson et la rareté de scènes de repas dans les pièces qu'il a écrites pour la troupe des Children of the Revels. Elles s'opposent en cela aux pièces écrites par ses contemporains pour cette même troupe théâtrale, dans lesquelles de telles scènes abondent. Cette étude portera sur leur absence dans The Case is Altered, Cynthia's Revels, Epicœne and Poetaster en s'appuyant sur les recherches actuelles concernant l'aspect matériel de la scène de théâtre, en particulier celles de Natasha Korda, Andrew Gurr et Andrew Sofer, ainsi que sur les études centrées exclusivement sur une seule troupe de théâtre, en particulier les travaux de Lucy Munro, Scott McMillin et Sally-Beth MacLean, afin d'offrir une nouvelle perspective sur l'attitude de Jonson vis-à-vis des contingences matérielles de la scène de théâtre.

$\mathrm{T}$

his paper focuses on the paucity of stage properties from which food and drink can be consumed in the plays Jonson wrote for The Children of the Revels. ${ }^{1}$ Although Jonson has been the subject of much critical attention, there has yet to be a study of his plays that focuses in a detailed manner on his use of stage properties. This paper forms a segment of my wider research that will address this significant gap. As theorizing stage properties is particularly difficult, owing to the dearth of accurate records of property use, I use the earliest print edition of each play, examining stage directions and business, in order to ascertain the likely properties that would be needed to stage it.

\footnotetext{
${ }^{1}$ As I am more concerned with Jonson than The Children of the Revels, and for ease of reference, I will refer to the company as The Children of the Revels throughout this paper.
} 
Asserting that Jonson has a very different authorial vision from his contemporaries writing for the Children of the Revels means my research into stage properties offers a challenge to much recent criticism of theatrical companies by Lucy Munro in Children of the Queen's Revels: A Jacobean Theatre Repertory ${ }^{2}$ and by Scott McMillin and Sally-Beth MacLean in The Queen's Men and their Plays, ${ }^{3}$ who have argued that the influence of theatrical company resources shapes early modern dramaturgy more than individual authors from the period could. This re-centring of responsibility for scenic form and design places the freelance and non-company playwrights back in the position of authors and away from the scriptwriters that recent scholars have attempted to make them. As part of this project to reassert the value of the author, I will study Jonson's poetry and biography in relation to The Children of the Revels' plays. Jonson's Revels' plays are Cynthia's Revels, Epicœne, The Poetaster, The Case is Altered and Eastward Ho!, which was written in collaboration with Marston and Chapman. My main focus will be the interplay of properties and characters' identities in Epicœne. Depictions of consumption are common in both Jonson's poetry and biography: in "Leges Conviviales" Jonson demonstrates a huge interest in drinking "good wine", which he suggests drinkers should "delight in excess"; the space in which he drinks, and the people with whom he drinks. 4 The environment provides a space in which conviviality can occur. In "To Penshurst”, Jonson delineates a version of drinking suitable for the aristocracy. He depicts an idyllic society in which

no man tells my cups; nor, standing by,

A waiter, doth my gluttony envy:

But gives me what I call for, and lets me eate. 5

Thus, Jonson believes food and drink should be made freely available by courteous waiters and drinking should be allowed to be immoderate. In his poetry, Jonson views drinking as a marker of social

\footnotetext{
${ }^{2}$ Lucy Munro, Children of the Queen's Revels: A Jacobean Theatre Repertory, Cambridge, Cambridge University Press, 2005

3 Scott McMillin and Sally-Beth MacLean, The Queen's Men and their Plays, Cambridge, Cambridge University Press, 1998.

4 Ben Jonson, "Leges Conviviales", The Workes of Ben Jonson, London, Thomas Hodgkin, 1692, Early English Books Online, accessed 12 April 2011, p. xi.24; vii.16 on 747-8.

5 Ben Jonson, "To Penshurst", The workes of Benjamin Ionson, London, Richard Bishop [and Robert Young], 1640, Early English Books Online, accessed 12 April 2011, p. 67-9.
} 
refinement, as Adam Smyth observes, "Ben Jonson, for instance celebrated drunkenness in manuscript (and later printed) poetry as a marker of social exclusivity, and drew a connection between hard drinking and elite poetic wit". ${ }^{6}$ Jonson also demonstrates his interest in convivial and socially refined hosting in "Inviting a friend to supper" in which he describes the food that should be served, the "canary wine" that is required and how he should be allowed the wine that was the "mermaids". In this description Jonson participates in a wider discourse outlined by Jeanneret:

In the Renaissance educated and cultured people, concerned about elegance and civility, established a vast network of precepts to oversee table manners: lessons on conduct, advice on the menu, rules about the service. $^{8}$

Jonson's poem, quintessentially early modern in its concerns with manners, fits into the body of work, which focuses on this specific cultural concern. However, the representation of tables - and the manners concomitant to this - in Jonson's dramatic work is more complex. I will begin by examining the dichotomy in Jonson's work: namely, that the popular image of Jonson gleaned through his biography and poetry, as a man with great interest in elegant dining habits and taverns is diametrically opposed to the meager appearance of convivial banqueting with wealthy members of society and the properties associated with drinking in a tavern in his plays for The Children of the Revels.

The recurring interest in imbibing alcohol that can be discerned in Jonson's poetry is closely allied to what we know of his biography. An infamous account of Jonson's drunkenness is given in "Heads of a conversation betwixt the famous poet Ben Jonson and William Drummond of Hawthornden", in which Jonson describes how at "his first communion, in Token of his true Reconciliation, he drunk out the

6 Adam Smyth, “It were far better to be a Toad or a Serpent, than a Drunkard': Writing about Drunkenness", A Pleasing Sinne: Drink and Conviviality in Seventeenth-Century England, ed. Adam Smyth, Cambridge, D. S. Brewer, 2004, p. 193

7 Ben Jonson, "Inviting a friend to supper", Epigrammes (CI), The Workes, op. cit., p. 30.

8 Michel Jeanneret, A Feast of Words: Banquest and Table Talk in the Renaissance, trans. Jeremy Whiteley and Emma Hughes, Chicago, University of Chicago Press, 1991, p. 3. 
full Cup of wine". ${ }^{9}$ Other infamous moments of Jonson getting drunk include his trip to Paris with Walter Raleigh's son during which Raleigh's son paraded the drunken Jonson through the streets in a wheelbarrow. ${ }^{10}$ William Drummond offers a general impression of Jonson's obstreperous nature, particularly when drunk,

Ben Johnson was a great Lover and Praiser of himself, a Contemner and Scorner of others, given rather to lose a Friend than a Jest; jealous of every Word and Action of those about him, especially after Drink, which is one of the Elements in which he lived. ${ }^{11}$

Despite writing about drinking, often extolling the virtues of public houses, and according to William Drummond, drink being "one of the elements in which he [that is Jonson] liveth", Jonson has fewer instances of dramatised drinking and eating in the plays that he wrote for the Children of the Revels than do other playwrights writing for the same company, such as Chapman, Marston, Beaumont and Fletcher. Jonson has one banquet in act four of The Poetaster, drinking in Cynthia's Revels and animal cups and meat are needed in Epicone. By contrast, in the three Children of the Revels plays by Beaumont and Fletcher - The Coxcomb, Cupid's Revenge and The Scornful Lady there are four scenes in which food is consumed. Similarly, in plays by Marston, items for eating are needed in The Malcontent; eating and drinking occurs in the first act of The Fawn; a poisoned bowl of wine is used in Sophonisba; a goblet in The Insatiate Countess; and a table of wine and glasses are needed in The Dutch Courtesan. Similarly, Chapman has a high usage of drinking and eating properties in the comedies for the Revels. In All Fools, cups, chairs and tables are needed in the final act; sack and its containers are used in The Gentleman Usher and a supper is staged at the end of Sir Giles Goosecap.

A reductive approach to these absences in Jonson's plays would ascribe them to Jonson's anti-theatrical prejudice; Jonas A. Barish

${ }^{9}$ William Drummond, "Heads of a conversation betwixt the Famous Poet Ben John and William Drummond of Hawthornden, January, 1619", The Works of William Drummond, 1640, Early English Books Online, accessed 12 April 2011, 224.

${ }^{10}$ Charles H. Herford, Percy Simpson and Evelyn Simpson, eds., Ben Jonson: Volume 1, Oxford, Clarendon Press, 1954, p. 64-5.

${ }^{11}$ Drummond, op. cit., p. 226. 
avers that Jonson had "deeply rooted antitheatricalism". ${ }^{12}$ My research offers a direct rebuttal to suggestions that Jonson's drama is underpinned by antitheatricalism, as stage properties are used to great dramatic effect. Furthermore, it is only within the children's plays that Jonson has a scarcity of properties linked to conviviality; he has no such difficulties representing eating and drinking in his masques and plays for the adult companies. Bartholomew Fair, for example, abounds with food and drink, from Ursula's ale to Quarlous forgetting his earlier conversation with Littlewit.

In Eastward Ho!, written with Marston and Chapman, drinking appears but only in the sections with which Jonson is not associated. All three of the most commonly accepted theories about the authorship of this play - by Parrott, Simpson and Petter - concur that the tavern scene in which Touchstone encourages Quicksilver to have another drink - "lay one cup of sack more a your cold stomack" -was written by Chapman. ${ }^{13}$ Furthermore, two out of three agree that the earlier scene when Touchstone encourages the drunken Quicksilver to have another drink was written by Marston. However, the actual drinking remains unstaged so this does not disrupt my conception of the play should it have been written by Jonson. The other tavern scene, in which Sir Petronell Flash tells Captain Seagull that they will have "supper brought a bord Sir Francis Drakes ship that hath compast the world: where with full Cupps and Banquets we wil doe sacrifice for a prosperous voyage", ${ }^{14}$ was also written by Chapman. ${ }^{15}$ This scene is also staged, as the authors inform us: "they compasse in Wynnifrid, daunce the drunken round, and drinkecarousses". ${ }^{16}$ That Jonson has so few instances of dramatised drinking across the other four plays for the Children of the Revels suggests a deliberate authorial design. Thus, the author has - at least some - control of the properties used in the

\footnotetext{
12 Jonas Barish, The Antitheatrical Prejudice, Berkeley and Los Angeles, University of California Press, 1981, p. 132.

13 R. W. Van Fossen, ed., Eastward Ho!, Manchester and New York, Manchester University Press, 1999.

14 I have followed Sir Petronell Flash in calling this a banquet, despite it not being "an afterdinner desert course, or an especially elaborate side refreshment after an evening's entertainment, either a masque or a party", which is the definition given by Chris Meads in Banquets Set Forth: Banqueting in English Renaissance Drama, The Revels Companion Library, Manchester, Manchester University Press, 2001, p. 10.

15 George Chapman, Ben Jonson and John Marston, Eastward Hoe, London, George Eld, 1605, Early English Books Online, accessed 12 April 2011, F1r.

${ }^{16}$ Eastward Ho!, op. cit., F1v.
} 
play: the author's preferences were not wholly ignored by the theatre's stakeholders.

In my reading of Epicœene I will focus on the absence of maledominated environments, such as the tavern and ale-houses; alehouses were conceived as specifically male, culturally problematic environments in which lower-class members of society acted against societal rules, sometimes violently challenging hegemonic order. Michelle O'Callaghan notes that

The public drinking house was a vital social space in early modern society. Inns, taverns, and alehouses were, in the words of Peter Clark, "indispensable social agencies", focal meeting places for the community where business and trade could be conducted, information exchanged, political issues debated, and social rituals performed. ${ }^{17}$

These social rituals are succinctly noted in "Leges Convivales" in which Jonson explicitly draws attention to the omission of female drinkers in these spaces, describing how each man should "pay his shot". ${ }^{18}$ Women are reduced to being a "mate", the choice of which, Jonson believes, should not be "debarred" by anyone. ${ }^{19}$ The tavern is Jonson's "Club room"; it is an exclusively male environment in which men drink and talk. Omitting this male-dominated environment - and by extension, the conviviality of having men sat around a tavern table means that the male gender is constructed differently. No longer is there a sense of shared purpose, as in Eastward Ho! when the drunken characters discuss the wealth they will make from war. In Marston's The Malcontent - a play also performed by The Children of the Revels - Malevole suggests to Mendoza "shals go to supper, Lets be once drunke together, and so vnite a most virtuously strengthened friendship". ${ }^{20}$ As expected, social ties are confirmed and strengthened through the presence of stage properties. In Shakespeare's infamous drinking scene in Antony and Cleopatra, Pompey demonstrates the power of the pirate forces by encouraging the feeble Lepidus to drink himself into oblivion. Thus inebriated, the latter takes Antony's ridiculous description of crocodiles at face value:

\footnotetext{
${ }^{17}$ Michelle O'Callaghan, “Tavern Societies, the Inns of Court, and the Culture of Conviviality in Early Seventeenth-Century London", A Pleasing Sinne, op. cit., p. 37.

18 "Leges Conviviales", op. cit., I.1.

19 Ibid., III.5.

${ }^{20}$ John Marston, The Malcontent, London, William Aspley, 1604, Early English Books Online, accessed 12 April 2011, D4r.
} 
LEPIDUS. What manner o' thing is your Crocodile?

ANTONY. It is shaped, sir, like itself, and it is as broad as it hath breadth. It is just so high as it is, and moves with it own organs. It lives by that which nourisheth it, and the elements once out of it, it transmigrates.

LEPIDUS. What colour is it of?

ANTONY. Of it own colour too.

(II.vii.40-45) $)^{21}$

Drinking can both reaffirm - and destroy - male social bonds. According to Jonson's poetry, the tavern is the most sacred of these male drinking environments. Paradoxically, throughout his plays for The Children of the Revels, whenever Jonson does represent drinking and eating, these are completed within the household environment, as in Epicœene, or related to classical environment, as in the "poeticall", "high" and "heauenly" banquet in The Poetaster and drinking from the spring in Cynthia's Revels, which are markedly different to the drinking scenes in The Malcontent, Antony and Cleopatra and Eastward Ho!. ${ }^{22}$

Although there is drinking and sociability in Epicœene, Jonson does not allow them to come to represent male sociability in the way that "Leges Conviviales" does: any drinking that does happen occurs in the domestic environment, which has already been demarcated as a female environment. Properties for drinking and eating are closely linked to gender identity throughout this play. The typical relationship between men and consumption of alcohol is disrupted, as the animal cups are Mrs Otter's, and the conversation turns not to poetry but to Mrs Otter's ownership of the house: she is "determined to raigne in mine owne house". ${ }^{23}$ It is therefore a very different environment from the "gatherings of men" to which Michelle O'Callaghan referred and that were culturally problematic. Drinking out of the Otters' cups in a homely environment over which Mrs Otter has great control means that the men are not separated from the women as they are in many drinking scenes of the period.

The drinking properties in Epicœene mirror and develop the blurred gender identities through the play. Typically, critics analyse

\footnotetext{
${ }^{21}$ Antony and Cleopatra, in The Oxford Shakespeare: The Complete Works, second edition, eds. Stanley Wells and Gary Taylor, Oxford, Oxford University Press, 2005.

22 Ben Jonson, The Poetaster, London, R. Bradock, 1602, p. 313, 319, 313.

23 Ben Jonson, Epicœene, in The Workes of Benjamin Jonson, London, Will Stansby, 1616, Early English Books Online, accessed 12 April 2011, p. 553.
} 
Epicœne's peruke, the removal of which reveals her to be a man. ${ }^{24}$ Instead, I will focus on the table properties and their gender implications. Thus, I take a different position on the importance of the cups to that of Juana Green, whose "Properties of Marriage: Proprietary Conflict in Epicoene" is the only other lengthy study of the importance of these cups: Green argued that "the carousing cups occupy a central position in the two scenes of domestic conflict between Captain and Mrs Otter", arguing that "Ben Jonson exploits the ability of stage properties to materialize, in spectacular form, early modern cultural concerns about shared marital property". ${ }^{25}$ Rather than being merely related to marriage concerns, the cups have a wider significance for the rest of the play, demonstrating a network of complex gender relations that have not been wholly explored.

At the outset of the play, Epicœne, who is described by Morose as "exceeding faire and of a speciall good fauour", ${ }^{26}$ and "the masculine construction of female perfection" 27 by Jean E. Howard, has very few stage properties associated with her. ${ }^{28}$ Lady Haughty draws attention to this:

wee see no ensignes of a wedding, here; no character of a brideale: where be our skarfes, and our gloues? I pray you, give 'hem vs. Let' know your brides colours and yours, at least [...] no gloves? No garters? No scarves? No epithalamium? ${ }^{29}$

Epicœne is divorced from objects; the play suggests that a character associated with very few properties is feminine. Focusing on the bride ale, "a wedding-feast of the Old English type" and "an ale-

\footnotetext{
24 See for instance, Marjorie Swann, "Refashioning Society in Ben Jonson's Epicoene", Studies in English Literature 38.2 (Spring 1998), p. 297-315, and Richmond Barbour "When I acted Young Antinous': Boy Actors and the Erotics of Jonsonian Theater", PMLA 1105 (Oct. 1995), p. 1006-1022.

25Juana Green, "Properties of Marriage: Proprietary Conflict and the Calculus of Gender in Epicoene”, Staged Properties in Early Modern English Drama, eds. Natasha Korda and Jonathan Gil Harris, Cambridge, Cambridge University Press, 2006, p. 261, 263.

${ }^{26}$ Epicœene, op. cit., p. 548.

27 Jean E. Howard, The Stage and Social Struggle in Early Modern England, London, Routledge, 1994, p. 107.

28 Edel Lamb argues similarly that "through the course of the play Epicœne is transformed from an ideal version of femininity (the silent woman) to a masculine and loud amazon" Performing Childhood in the Early Modern Theatre: The Children's Playing Companies (1599-1613), Palgrave Macmillan, Houndsmills, 2008, p. 38.

${ }^{29}$ Epicœene, op. cit., p. 563.
} 
drinking at a wedding”,30 Lady Haughty specifically draws attention to the importance of food and drink for festal purposes and how the omission of such ritual consumption signifies a lack - "no ensigns". By contrast, Mrs Otter, whose "teeth were made i'th Blacke-Friers: both her eyes i'th Strand, and her haire in Siluer-street. Euery part o'th towne ownes a peece of her" is an amalgamation of disparate parts of London; her body is assembled from a multitude of objects. ${ }^{31}$ Mrs Otter is the very opposite of female perfection. Mr Otter's masculinity is created through the cups; True-wit informs Dauphine that Tom Otter

Has been a great man at the beare-garden in his time: and from that subtle sport, has tane the witty denomination of his chiefe carousing cups. One he calls his bull, another his beare, another his horse. And then he has his lesser glasses, that he calls his deere, and his ape; and seuerall degrees of 'hem too: and neuer is well, nor thinkes any intertainement perfect, till these be brought out, and set o'th cupbord. ${ }^{2}$

The cups are inextricably bound to ideas of Otter's power - his being a "great man" at the "beare-garden". As I have demonstrated above, identity throughout Epicœne is demarcated through characters' relationships to properties. The cups in Epicœene come to act as prosthetic signifiers of gender in ways usually associated with swords and beards. 33 Yet, the cups have already been femininised. The network of characters associated with the cups demonstrates that, in addition to the peruke, Jonson used other properties in more nuanced and complex ways in order to explore the liminal status of the gender. Although Jonson uses swords, the traditional signifiers of masculinity, to demonstrate Morose's lack of masculinity through having him enter with the weapons stolen from Daw and LaFoole, cups provide another layer of important meaning.

Unlike the characters in Eastward Ho!, the men do not access the tavern. The Otters' cups and noise gradually turn Morose's life into chaos. The unruly properties play a large role not in integrating Morose into society but excluding him from it, the reverse of what happens in specifically male environments. Jean E. Howard notes, "Epicœne joins

\footnotetext{
$3^{\circ}$ Oxford English Dictionary Online.

${ }^{31}$ Epicœene, op. cit., p. 569.

32 Epicone, op. cit., p. 552.

33 See Will Fisher's Materializing Gender in Early Modern English Literature and Culture, Cambridge, Cambridge University Press, 2006, for a reading of other prostheses that constructed gender.
} 
the Collegians and outdoes them in filling Morose's house with noise, food and luxuries". 34 Through developing especially close relationships between characters and properties that are then endowed with gendered meanings, this play systematically deconstructs gender binaries. Morose's masculinity should be seen through the presence of his sword, and his ability to cope with the animal cups.

The characterisation of Morose - and others - demonstrates Jonson's apparent reluctance to represent drinking on the stage when the plays are performed by a boys' company. This could represent an anxiety about children acting as men in male environments. As boys were conceived of as incomplete men, they were more commonly linked to women - also incomplete men - than to men. ${ }^{35}$ This cultural construction of age and gender probably also offers a reason why Jonson allows the boys access to the feminised domestic environment, with its concomitant issues of marriage, but not to the specifically male environments. Through these child companies, masculinity was necessarily reduced to being represented by prosthetic attachments, such as wigs, beards and swords ${ }^{36}$ - these properties (and the words the characters speak) are the only differences between boys and men. Jonson's Epicoene plays with the notion of a prosthetic construction of gender and stage properties associated with drinking and eating are at the locus of this representation of the construction of gender identity in Epicœne. Edel Lamb argues that Dauphine's boy who dresses up as Epicœne represents "gender identity in flux" but that Morose loses his sword, takes two others and then loses his house through his inability to cope with objects suggests a consistently fluxing gender identity, as compared to Epicœne's single change from male to "female". 37

Through the Children of the Revels' plays, Jonson does not portray tobacco, although it could easily be represented with hand

34 Howard, op. cit., p. 107. Karen Britland argues in "Circe's Cup: Wine and Women in Early Modern Drama" that women can "divert a man from his proper public role [...] and carry him into chaos", in Adam Smyth ed., A Pleasing Sinne, op. cit., p. 109-125, here p. 111. 35 See Stephen Orgel's "Nobody's Perfect: Or Why Did the English Stage Take Boys for Women?", South Atlantic Quarterly 88, 1989, for ideas about the "interchangeability" of women and boys in the early modern period. See also Jeri Tanner, The Dramatic and Narrative Influence of Tobacco on Literature of the Renaissance: A Dissertation in English, Texas Technical College, 1968, Available at:

<etd.lib.ttu.edu/theses/available/etdo9012009/31295010786423.pdf>. 13 April 2011. 152.

36 Ben Jonson, Epigrammes (CXX), The Workes, op. cit., p. 38.

${ }^{37}$ Lamb, op. cit., p. 37. 
props on stage. In The Alchemist Jonson labels Abel Drugger as a "seller of tobacco", and Jeri Tanner describes Ben Jonson as "an accomplished satirist" 38 who "uses tobacco to characterize swindlers and gulls simultaneously", but he evades the issue of tobacco through his Revels' plays. ${ }^{39}$ Access to properties was certainly not an issue, as Marston refers to it in the Prologue of The Malcontent and Field stages tobacco in Amends for Ladies, to name but two examples. Once again, comparing Jonson's property use to that of his contemporaries enforces the individuality of Jonson's dramatic vision, in addition to his molding of property use to evade the impressionable boy actors having to use them on stage.

There are two main effects from Jonson's omission of tobacco and male drinking environments. Firstly, Jonson protects the dramatic representation of one of his favourite environments from being parodied by children. Jonson's antitheatrical prejudice is, of course, redolent in this idea. Secondly - and more importantly, Jonson does not allow the boys access to this explicitly male type of drinking and cultural occurrence, even through the medium of acting. In this reading, we conceive Jonson in a similar way to the way he is considered after reading "Epitaph on S. P. a Child of Q. El Chappel”,40 which demonstrates a dramatist who is interested in the children for whom he wrote, describing Salomon Pavy as a "stage jewel". Envisioning Pavy as a "stage jewel" could suggest that Jonson saw Pavy as a young boy whose shining, jewel-like status could bring in many playgoers. However, the same cannot be said of Jonson's "On my first sonne": ${ }^{41}$ Jonson's soft language, the subtly altered "rest in soft peace", as opposed to the usual "rest in peace", as well as the line "thou child of my right hand" could suggest not only how upon reaching adulthood, the child would work alongside Jonson, but also references to "hands" inculcate the notion of writing and suggest Jonson's poetic art was influenced by the child. The overwhelming weight of Jonson's written words point towards his being interested in the welfare of children,

\footnotetext{
$3^{8}$ Jeri Tanner, op. cit.

39 Ben Jonson, The Alchemist, London, Thomas Snodham, 1612, Early English Books Online, accessed 12 April 2011, C2r.

$4^{\circ}$ Ben Jonson, Epigrammes (CXX), The Workes, op. cit., p. 38.

${ }^{41}$ Ben Jonson, Epigrammes (XLV), The Workes, op. cit., p. 14-15.
} 
which works against the less salubrious instances of Jonson getting drunk while in charge of a child, in the case of Walter Raleigh's son.

To conclude, Jonson refuses to let children gain access to the adult world of drinking in taverns - even through the medium of performance. In so doing, he goes against a wide range of work by his contemporaries, as we have discussed through this conference. When the boys do drink - and sit at tables - it is only in the domestic environment of Epicoene, in Cynthia's Revels and when acting as poets in The Poetaster. Thus, when the drinking environment is distanced from the culturally problematic taverns, the boys are allowed to drink. The absence of taverns leads to an absence of certain social rituals that confirm the male identity. The male identity is problematised particularly in Epicoene through this lack of male environment. The absences that I have identified point towards Jonson's concern for children, rather than just being an anti-theatrical prejudice. Although this is a microcosm of my research, it also points to the centrality of authorship to property use, that is to the ways in which property use can be used to reflect on authorial behaviour and to create alternative conceptions of plays.

Joanne VINE Anglia Ruskin University 